\title{
Pengaruh Pemanfaatan Laboratorium IPA Terhadap Hasil Belajar Siswa pada Mata Pelajaran IPA di SMP Negeri 1 Wangi-Wangi
}

\author{
Zul Arham ${ }^{1} ;$ Usman $^{2} ;$ Samrin $^{1} ;$ Jumarddin La Fua $^{1}$ \\ 1) Dosen Fakultas Tarbiyah dan Ilmu Keguruan (FTIK), Institut Agama Islam Negeri (IAIN) Kendari; \\ 2) Alumni Prodi Tadris IPA, FTIK, IAIN Kendari \\ Email Korespondensi : zul.arham.kim@gmail.com
}

\begin{abstract}
This article is a quantitative study that aims to find out: (1) Student learning outcomes before the utilization of the Natural Sciences laboratory at SMP Negeri 1 Wangi-Wangi, (2) Student learning outcomes after the utilization of the Science Laboratory at SMP Negeri 1 Wangi-Wangi, (3) Effects the use of science laboratories for student learning outcomes in science subjects in Wangi-Wangi State Junior High School. The research design uses a one group pretest posttest design, meaning that the assessment is carried out to measure students 'ability by providing a pretest to measure students' mastery of concepts before treatment, and posttest to measure mastery of concepts after treatment. The population of this study was students of class VIII E of SMP Negeri 1 Wangi-Wangi. Data analysis techniques were performed using descriptive analysis and inferential analysis. The results showed that (i) Student learning outcomes before the utilization of the Natural Sciences laboratory obtained an average value in the posttest class that is 52 based on the category of learning outcomes in the low category. (ii) Student learning outcomes after the utilization of the Natural Sciences laboratory obtained an average score in the 78.25 pretest class based on the category of learning outcomes in the high category. (iii) There is a positive influence between the use of science laboratories on student learning outcomes in natural science subjects, after the t test is obtained tcount> ttable or 8.33>2.042.
\end{abstract}

Keywords: Learning Outcomes, Science Laboratory, Wangi-Wangi Public Middle School

\begin{abstract}
ABSTRAK
Artikel ini adalah penelitian kuantitatif yang bertujuan untuk mengetahui: (1) Hasil belajar siswa sebelum pemanfaatan laboratorium IPA di SMP Negeri 1 Wangi-Wangi, (2) Hasil belajar siswa setelah pemanfaatan laboratorium IPA di SMP Negeri 1 Wangi-Wangi, (3) Pengaruh pemanfaatan laboratorium IPA terhadap hasil belajar siswa pada mata pelajaran IPA di SMP Negeri 1 Wangi-Wangi. Desain penelitin menggunakan desain one group pretest postest, artinya penilaian yang dilakukan untuk mengukur kemampuan siswa dengan cara memberikan pretest untuk mengukur penguasaan konsep peserta didik sebelum perlakuan, dan postest untuk mengukur penguasaan konsep setelah perlakuan. Populasi penelitian ini adalah peserta didik kelas VIII E SMP Negeri 1 Wangi-Wangi. Tehnik analisis data yang dilakukan dengan menggunakan analisis deskriptif dan analisis inferensial. Hasil penelitian menunjukkan bahwa (i) Hasil belajar siswa sebelum pemanfaatan laboratorium IPA memperoleh nilai rata-rata pada kelas postest yaitu 52 berdasarkan kategori hasil belajar berada pada kategori rendah. (ii) Hasil belajar siswa setelah pemanfaatan laboratorium IPA memperoleh nilai rata-rata pada kelas pretest 78,25 berdasarkan kategori hasil belajar berada pada kategori tinggi. (iii) Terdapat pengaruh positif antara pemanfaatan laboratorium IPA terhadap hasil belajar siswa pada mata pelajaran IPA, setelah dilakukan uji $\mathrm{t}$ diperoleh $\mathrm{t}_{\text {hitung }}>\mathrm{t}_{\text {tabel }}$ atau 8,33 $>2,042$.
\end{abstract}

Kata Kunci: Hasil Belajar, Laboratorium IPA, SMP Negeri 1 Wangi-Wangi

\section{PENDAHULUAN}

Laboratorium menjadi salah satu sarana pendukung kelancaran kegiatan pembelajaran. Dengan adanya laboratorium, peserta didik dapat mengembangkan kemampuan berteknologi melalui peralatan yang ada di dalamnya. Siswa lebih mudah dalam mencari sumber-sumber belajar yang mereka inginkan. Keberadaan laboratorium (kegiatan praktikum) di sekolah dapat mendukung kegiatan pembelajaran serta mencapai ranah tujuan pendidikan yaitu salah satunya ranah kognitif (Hosfein A. \& Naaman R.M., 2011). Belajar dengan mengaplikasikan teori dalam bentuk kegiatan laboratorium (praktikum) dapat meningkatkan kemampuan proses, kemampuan menyelesaikan masalah dan meningkatkan minat serta sikap siswa terhadap pembelajaran. Laboratorium sangat diperlukan sebagai tempat belajar untuk memberikan pengalaman nyata pada siswa sebagai salah satu faktor pendukung pelaksanaan pembelajaran. Kegiatan laboratorium tidak hanya bertujuan untuk meningkatkan teori, tetapi siswa dapat menemukan pengetahuan sendiri (Feyzioglu B., 2012).

Hakikatnya pembelajaran teori dan praktikum di laboratorium merupakan kegiatan-kegiatan yang tidak terpisahkan dalam proses belajar mengajar (PBM) pada mata pelajaran IPA. Dimana ilmu IPA sebagai bagian 
dari sains memiliki karakterisitik yang dibangun dengan mengedepankan eksperimen sebagai media/cara untuk memperoleh pengetahuan, kemudian dikembangkan atas dasar pengamatan, pencarian, dan pembuktian. Kegiatan praktikum yang dilakukan di laboratorium merupakan metode yang memberikan pengaruh terhadap keberhasilan siswa dalam belajar IPA (Nur Raina N., 2010). Pernyataan tersebut diartikan bahwa kegiatan laboratorium dapat membangun sendiri pengetahuan tentang fakta, konsep, dan teori yang terdapat dalam materi IPA (Ilmu Pengetahuan Alam) serta memperkaya pengalaman sehingga akan bertahan lebih lama dalam ingatan siswa. IPA berkaitan dengan cara mencari tahu dan memahami alam secara sistematis, sehingga mata pelajaran IPA bukan hanya penguasaan kumpulan pengetahuan berupa fakta-fakta, konsep-konsep, prinsip prinsip saja tetapi juga merupakan suatu proses penemuan. Pendidikan IPA dapat menjadi wahana bagi siswa untuk mempelajari dirinya sendiri dan alam sekitarnya, sehingga siswa akan lebih paham terhadap materi pelajaran dan hasil belajarnya dapat meningkat.

Hasil observasi di SMP Negeri 1 Wangi-Wangi menunjukkan bahwa nilai rata- rata IPA masih rendah ini terlihat yang tidak memperhatikan penjelasan ketika guru tersebut sedang mengajar dan banyak melakukan aktifitas lain diluar pembelajaran, hal ini disebabkan karena kegiatan belajar mengajar hanya menggunakan metode ceramah dengan bahan ajar buku paket sehingga siswa kurang memahami materi. Faktor yang mempengaruhi proses dan hasil belajar siswa adalah faktor lingkungan, faktor istrumental, kondisi fisiologis, dan kondisi psikologis. Faktor psikologis merupakan faktor utama yang mempengaruhi proses dan hasil belajar siswa dari dalam (Djamarah SB \& Zain A., 2012).

Belajar dengan mengaplikasikan teori dalam kegiatan laboratorium (praktikum) dapat meningkatkan kemampuan proses, kemampuan menyelesaikan masalah dan meningkatkan pengetahuan siswa dalam pembelajaran. Laboratorium sangat diperlukan sebagai tempat belajar untuk memberikan pengalaman nyata pada siswa sebagai salah satu faktor pendukung pelaksanaan pembelajaran. Kegiatan laboratorium tidak hanya bertujuan untuk meningkatkan teori, tetapi siswa dapat menemukan pengetahuan sendiri (Feyzioglu B., 2012). Semakin tinggi keterlibatan siswa dalam kegiatan praktikum semakin tinggi pencapaian pemahaman siswa. Pendidikan IPA berkaitan dengan cara mencari tahu dan memahami alam secara sistematis, sehingga IPA bukan hanya penguasaan kumpulan pengetahuan berupa fakta-fakta, konsep-konsep, prinsip-prinsip saja tetapi juga merupakan suatu proses penemuan (Depdiknas., 2013) Pendidikan IPA dapat menjadi wahana bagi siswa untuk mempelajari dirinya sendiri dan alam sekitarnya, sehingga siswa akan lebih paham terhadap materi pelajaran dan hasil belajarnya dapat meningkat. Berdasarkan identifikasi masalah di atas, maka rumusan masalah pada penelitian: (1) Bagaimana hasil belajar siswa sebelum pemanfaatan laboratorium IPA di SMP Negeri 1 WangiWangi ? (2) Bagaimana hasil belajar siswa setelah pemanfaatan laboratorium IPA di SMP Negeri 1 WangiWangi ? (3) Bagaimana pengaruh pemanfaatan laboratorium IPA terhadap hasil belajar siswa pada mata pelajaran IPA di SMP Negeri 1 Wangi-Wangi ?

\section{METODE PENELITIAN}

Penelitian ini adalah penelitian yang menggunakan pendekatan kuantitatif deskriptif eksperimental. Populasi penelitian ini adalah siswa kelas VIII SMP Negeri 1 Wangi-Wangi yang berdistribusi dalam 5 kelas dengan jumlah siswa sebanyak 104 orang. Adapun penarikan sampel dalam penelitian ini adalah ditetapkan dengan teknik Purposive Random Sampling artinya menentukan kelas sampel secara langsung, yaitu menetapkan 1 (satu) kelas adalah kelas VIII E sebagai kelas penelitian dengan jumlah siswa sebanyak 20 siswa semester genap tahun ajaran 2018/2019. Pengambilan sampel ini dilakukan dengan pertimbangan bahwa sampel tersebut memiliki kemampuan rata-rata yang relatif rendah, maka kelas VIII E sudah dapat mewakili populasi. Rancangan penelitian ini adalah menggunakan desain one group pretest-postest (Sugiono., 2014). Prosedur yang dilakukan adalah kelas tersebut diberikan pretest yaitu tes sebelum pemanfaatan laboratorium IPA, setelah itu diberikan perlakuan dengan menggunakan pemanfaatan laboratorium IPA dan selanjutkan diberikan postest yaitu tes dengan pemanfaatan laboratorium IPA.

Untuk memenuhi kriteria etika penelitian, sejak awal peneliti menyusun proposal penelitian dan mengkomunikasikan dengan kepala sekolah dan meminta pertimbangan awal terhadap pertanyaan penelitian yang diajukan. Proposal penelitian selanjutnya diseminarkan di Institut Agama Islam Negeri Kendari Januari 2019 untuk menguji kelayakan proposal penelitian. Pengumpulan data dilakukan selama 3 bulan, dari januari 2019 sampai maret 2019. Tehnik pengumpulan data yaitu observasi, tes dan dokumentasi. Teknik observasi adalah teknik pengumpulan data dengan cara mengadakan pengamatan langsung di lapangan, Tes, yaitu bentuk pertanyaan yang harus dijawab oleh siswa untuk mengetahui nilai-nilai hasil belajar yang dicapai oleh siswa dalam proses pembelajaran, Tes dilakukan untuk menguji kemampuan siswa dalam pembelajaran IPA pada materi tekanan zat dan penerapanya dalam kehidupan sehari-hari. Tes yang diberikan pada siswa berupa soal pilihan ganda dan Dokumentasi, yaitu dilakukan dengan cara mencatat dan menyalin data yang terdapat disekolah (jumlah siswa serta dokumen-dokumen lain yang berkaitan dengan topik penelitian). sedangkan analisis data yang digunakan yaitu analisis deskriptif (range, mean, median, modus, varians dan standar deviasi) dan analisis inferensial (uji normalitas, uji homogenitas dan hipotesis). Prosedur penelitian yang dilakukan ada 3 tahap yaitu tahap persiapan, tahap pelaksanaan dan tahap akhir. 


\section{HASIL PENELITIAN}

\section{Hasil Belajar Siswa Sebelum Pemanfaatan Laboratorium IPA}

Berdasarkan penelitian yang dilakukan di SMP Negeri 1 Wangi-Wangi pada kelas VIII E yang dijadikan sebagai kelas pretest pada penelitian ini yang diajar sebelum melakukan pemanfaatan laboratorium pada materi tekanan zat dan penerapanya dalam kehidupan sehari-hari, soal yang diberikan pada kelas tersebut sebanyak 20 soal dalam bentuk pilihan ganda. Berdasarkan analisis deskriptif menunjukan bahwa hasil belajar siswa sebelum pemanfaatan laboratorium, diperoleh nilai tertinggi 70 , nilai terendah 30, rata-rata (mean) 52, median 50,5, modus 61, range 40, banyak kelas 6, panjang kelas 7, standar deviasi 11,37 dan varians 129,47 dari 20 siswa. Skor hasil pengumpulan data dari instrumen variabel hasil belajar pada kelas pretest dapat dilihat dalam tabel distribusi frekuensi dan kategori hasil belajar sebagai berikut:

Tabel 1 Distribusi Frekuensi Nilai Pretest

\begin{tabular}{|c|c|c|c|}
\hline Kelas & Interval & F & Fr \\
\hline 1 & $30-36$ & 2 & $10 \%$ \\
\hline 2 & $37-43$ & 4 & $20 \%$ \\
\hline 3 & $44-50$ & 3 & $15 \%$ \\
\hline 4 & $51-57$ & 2 & $10 \%$ \\
\hline 5 & $58-64$ & 7 & $35 \%$ \\
\hline 6 & $65-71$ & 2 & $10 \%$ \\
\hline \multicolumn{2}{|r|}{ Jumlah } & $\mathbf{2 0}$ & $\mathbf{1 0 0 \%}$ \\
\hline
\end{tabular}

Dari tabel 1 jumlah siswa pada interval nilai 30-36 adalah 2 siswa atau 10\%. Jumlah siswa pada interval nilai 37-47 adalah 4 siswa atau 20\%. Jumlah siswa pada interval nilai $44-50$ adalah 3 siswa atau $15 \%$. Jumlah siswa pada interval nilai 51-57 adalah 2 siswa atau 10\%. Jumlah siswa pada interval nilai 58-64 adalah 7 siswa atau 35\%. Jumlah siswa pada interval nilai 65-71 adalah 2 siswa atau 10\%. Dari tabel juga dapat diketahui bahwa dari 20 butir soal pretest yang telah diberikan kepada 20 siswa maka diperoleh nilai siswa yang terbanyak adalah 58-64 berjumlah 7 orang atau 35\%. Untuk lebih jelasya hasil belajar siswa sebelum pemanfaatan laboratorium dapat dilihat pada tabel kategori hasil belajar sebagai berikut:

Tabel 2 Kategori Hasil Belajar Siswa Sebelum Pemanfaatan Laboratorium IPA

\begin{tabular}{|c|l|l|l|}
\hline Interval & Frekuansi & Persentase (\%) & Kategori \\
\hline $0-34$ & 2 & 10 & Sangat rendah \\
\hline $35-54$ & 7 & 35 & Rendah \\
\hline $55-64$ & 9 & 45 & Sedang \\
\hline $65-84$ & 2 & 10 & Tinggi \\
\hline $85-100$ & 0 & 0 & Sangat tinggi \\
\hline Jumlah & 20 & 100 & \\
\hline
\end{tabular}

Berdasarkan tabel 2 data kategori hasil belajar siswa pada interval 0-34 dengan persentase $10 \%$ tergolong kategori sangat rendah, interval 35-54 dengan persentase 35\% tergolong kategori rendah, interval 5564 dengan persentase $45 \%$ tergolong kategori sedang, dan interval 65-84 dengan presentase 10\% tergolong tinggi. Dengan demikian hasil belajar siswa sebelum pemanfaatan laboratorium IPA didominasi pada nilai yang berada pada kategori sedang dan rendah.

\section{Hasil Belajar Siswa Setelah Pemanfaatan Laboratorium IPA}

Hasil belajar siswa pada materi tekanan zat dan penerapanya dalam kehidupan sehari-hari di kelas VIII E SMP Negeri 1 Wangi-Wangi yang dijadikan sebagai kelas postest pada penelitian ini yang diajar dengan menggunakan pemanfaatan laboratorium, soal yang diberikan pada kelas tersebut sebanyak 20 soal dalam bentuk pilihan ganda. Berdasarkan analisis deskriptif menunjukan bahwa hasil belajar siswa sebelum pemanfaatan laboratorium, diperoleh nilai tertinggi 90, nilai terendah 65, rata-rata (mean) 80,15, median 80,92, modus 81,72, range 25, banyak kelas 6, panjang kelas 5, standar deviasi 7,60 dan varians 57,87 dari 20 siswa. Skor hasil pengumpulan data dari instrumen variabel hasil belajar pada kelas pretest dapat dilihat dalam tabel distribusi frekuensi dan kategori hasil belajar sebagai berikut: 
Tabel 3 Distribusi Frekuensi Nilai Postest

\begin{tabular}{|l|l|l|l|}
\hline Kelas & Interval & F & Fr \\
\hline 1 & $65-69$ & 2 & $10 \%$ \\
\hline 2 & $70-74$ & 3 & $15 \%$ \\
\hline 3 & $75-79$ & 3 & $15 \%$ \\
\hline 4 & $80-84$ & 7 & $35 \%$ \\
\hline 5 & $85-89$ & 2 & $10 \%$ \\
\hline 6 & $90-94$ & 3 & $15 \%$ \\
\hline Jumlah & & $\mathbf{2 0}$ & $\mathbf{1 0 0 \%}$ \\
\hline
\end{tabular}

Dari tabel 3 jumlah siswa pada interval nilai 65-69 adalah 2 siswa atau 10\%. Jumlah siswa pada interval nilai 70-74 adalah 3 siswa atau 15\%. Jumlah siswa pada interval nilai 75-79 adalah 3 siswa atau 15\%. Jumlah siswa pada interval nilai 80-84 adalah 7 siswa atau 35\%. Jumlah siswa pada interval nilai 85-89 adalah 2 siswa atau $10 \%$. Jumlah siswa pada interval nilai 90-94 adalah 3 siswa atau 15\%. Dari tabel juga dapat diketahui bahwa dari 20 butir soal postest yang telah diberikan kepada 20 siswa maka diperoleh nilai siswa yang terbanyak adalah 58-64 berjumlah 7 orang atau 35\%. \%. Untuk lebih jelasya hasil belajar siswa sebelum pemanfaatan laboratorium dapat dilihat pada tabel kategori hasil belajar sebagai berikut:

Tabel 4 Kategori Hasil Belajar Siswa Setelah Pemanfaatan Laboratorium IPA

\begin{tabular}{|l|l|l|l|}
\hline Interval & Frekuansi & Persentase $(\%)$ & Kategori \\
\hline $0-34$ & 0 & 0 & Sangat rendah \\
\hline $35-54$ & 0 & 0 & Rendah \\
\hline $55-64$ & 0 & 0 & Sedang \\
\hline $65-84$ & 15 & 75 & Tinggi \\
\hline $85-100$ & 5 & 25 & Sangat tinggi \\
\hline Jumlah & 20 & 100 & \\
\hline
\end{tabular}

Berdasarkan tabel 4 yaitu data kategori hasil belajar siswa setelah pemanfatan laboratorium IPA pada interval 65-84 dengan persentase 75\% tergolong kategori tinggi, dan interval 85-100 dengan presentase $25 \%$ tergolong sangat tinggi. Dengan demikian hasil belajar siswa setelah menggunakan pemanfaatan laboratorium IPA didominasi pada nilai yang berada pada kategori tinggi.

\section{Pengaruh Pemanfaatan Laboratorium IPA terhadap Hasil Belajar Siswa}

Hasil belajar siswa sebelum pemanfaatan laboratorium IPA dan setelah pemanfaatan laboratorium IPA dapat dilihat dengan membandingkan hasil setiap perlakuan sehingga perbedaan rata-rata hasil belajar siswa sebelum pemanfaatan laboratorium IPA dan setelah pemanfaatan laboratorium IPA dapat disajikan dalam tabel berikut:

Tabel 5 Perbedaan Rata-Rata Hasil Belajar Siswa Sebelum Pemanfaatan Laboratorium IPA dan Setelah Pemanfaatan Laboratorium IPA

\begin{tabular}{|l|l|l|l|}
\hline No & Statistik & Pretest & Postest \\
\hline 1 & Nilai hasil belajar tertinggi & 70 & 90 \\
\hline 2 & Nilai hasil belajar terendah & 30 & 65 \\
\hline 3 & Rata-rata & 52 & 78,25 \\
\hline
\end{tabular}

Berdasarkan tabel 5 diatas menunjukan bahwa hasil belajar siswa sebelum pemanfaatan laboratorium IPA memiliki nilai rata-rata sebesar 52 sedangkan setelah pemanfatatan laboratorium IPA memiliki nilai ratarata 78,25. Dengan adanya perbedaan hasil belajar tersebut, maka akan dilakukan uji t untuk mengetahui pengaruh pemanfaatan laboratorium IPA terhadap hasil belajar siswa. Sebelum melakukan uji t data yang diperoleh pada kelas pretest dan kelas postest akan dilakukan uji analisis prasyarat yaitu normalitas dan homogenitas. Uji normalitas digunakan untuk mengetahui sebaran data berdistribusi normal atau tidak sedangkan uji homogenitas digunakan untuk mengetahui sebaran data dari kedua sampel tersebut sama (homogen) atau tidak sama (heterogen).

Uji normalitas pada kelas pretest diperoleh $\mathrm{x}_{\text {hitung }}^{2}=6,32$. Dari daftar tabel nilai kritis Chi Kuadrat pada taraf signifikansi 0,05 diperoleh nilai $\mathrm{x}_{\text {tabel }}^{2}=11,07$. Diketahui bahwa nilai $\mathrm{x}^{2}{ }_{\text {hitung }}<\mathrm{x}_{\text {tabel }}{ }^{2}$ atau $6,32<11,07$ dan 
pada kelas postest diperoleh $\mathrm{x}_{\text {hitung }}^{2}=3,71$. Dari daftar tabel nilai kritis Chi Kuadrat pada taraf signifikansi 0,05 diperoleh nilai $\mathrm{x}_{\text {tabel }}^{2}=11,07$. Diketahui bahwa nilai $\mathrm{x}_{\text {hitung }}^{2}<\mathrm{x}_{\text {tabel }}^{2}$ atau 3,71 $<11,07$ dengan demikian dapat dinyatakan bahwa bahwa hasil belajar siswa yang diajar sebelum pemanfaatan laboratorium IPA merupakan sampel yang berasal dari populasi yang berdistribusi normal. Selanjutnya dilakukan uji homogenitas diperoleh nilai $F_{\text {hitung }}=2,39$ nilainya lebih kecil darai harga $F_{\text {tabel }}=4,41$ pada taraf signifikansi 0,05 karena $F_{\text {hitung }}<F_{\text {tabel }}$ sehingga kriteria penerimaan dapat disimpulkan bahwa data dari kedua sampel berasal dari populasi yang memiliki varians homogen. Kemudian uji hipotesis, pengujian hipotesis dilakukan untuk mengetahui pengaruh pemanfaatan laboratorium IPA terhadap hasil belajar siswa, diperoleh $\mathrm{t}_{\text {hitung }}=8,33$ dan $\mathrm{t}_{\text {tabel }}=2,042$. Dengan taraf signifikansi yang digunakan sebesar 5\% atau 0,05 maka $t_{\text {hitung }}>t_{\text {tabel }}$ atau 8,33>2,042 jadi Ha diterima dan Ho ditolak. Kesimpulanya terdapat pengaruh pemanfaatan laboratorium IPA terhadap hasil belajar siswa pada mata pelajaran IPA di SMP Negeri 1 Wangi-Wangi.

\section{PEMBAHASAN}

Hasil belajar pada siswa itu memiliki cakupan yang sangat luas. Dimana hasil belajar merupakan suatu pencapaian siswa setelah melakukan proses belajar dan hasil belajar tersebut dapat dilihat dari aspek pembelajaran selama proses belajar (Sardiman A. M.,2010). Laboratorium adalah suatu tempat yang dilengkapi dengan sarana/alat-alat dan bahan-bahan penunjang guna melakukan kegiatan praktikum agar dapat memperoleh pemahaman konsep secara optimal (K. S. K. Wardani., 2016). Hasil belajar siswa sebelum pemanfaatan laboratorium IPA, berdasarkan hasil penelitian yang telah dilakukan pada siswa kelas VIII E di SMP Negeri 1 Wangi-Wangi dengan jumlah siswa pada kelas tersebut 20 siswa. Kelas tersebut diberikan pretest dengan pembelajaran sebelum pemanfaatan laboratorium IPA pada materi tekanan zat dan penerapanya dalam kehidupan sehari-hari dengan memberikan 20 butir soal dalam bentuk pilihan ganda dengan maksud untuk mengetahui kondisi hasil belajar siswa atau kemampuan awal siswa.

Adapun nilai rata-rata nilai rata-rata pretest yang diperoleh pada kelas tersebut adalah 52 dari nilai ratarata yang diperoleh berdasarkan kategori hasil belajar maka hasil belajar pada kelas tersebut tergolong rendah dan dibawah rata-rata yang sudah ditetapkan sebelumya. Hasil belajar siswa pada kelas pretest yang diajar sebelum pemanfaatan laboratorium mendapatkan nilai kategori rendah terlihat pada saat proses pembelajaran yang hanya berlangsung didalam kelas sehingga siswa kurang aktif dan kurang termotivasi karena seharusnya pada materi tekanan zat dan penerapanya dalam kehidupan sehari-hari membutuhkan pemanfaatan laboratorium untuk mendapatkan pemahaman konsep, hal ini sejalan dengan teori yang dikemukakan oleh Nur raina novianti yang mengatakana bahwa salah satu fungsi dari pemanfaatan laboratorium adalah untuk memeperoleh pemahaman konsep (Nur Raina Novianto., 2010).

Setelah diberikan pretest kelas tersebut diberikan postest dengan melakukan pemanfaatan laboratorium IPA pada materi tekanan zat dan penerapanya dalam kehidupan sehari-hari dengn melakukan kegiatan praktikum berupa merancang alat pascal, mengamati gaya apung, dan transpirasi dalam tubuh tumbuhan. Setelah diberi perlakuan, pada akhir pertemuan peneliti memberikan postest dengan tujuan untuk mengetahui hasil belajar siswa setelah pemanfaatan laboratorium IPA, dengan jumlah soal yang digunakan sebanyak 20 butir dalam bentuk pilihan ganda. Adapun nilai rata-rata postest yang diperoleh pada kelas tersebut yaitu 78.25 dari nilai rata-rata yang diperoleh berdasarkan kategori hasil belajar maka hasil belajar pada kelas tersebut tergolong tinggi.

Hasil penelitian ini menunjukan bahwa pemanfaatan laboratorium IPA pada kelas tersebut sangat mempengaruhi hasil belajar siswa. Hal ini terlihat dalam peningkatan terhadap nilai rata-rata siswa sebelum diberi perlakuan 52 dan setelah perlakuan memiliki rata-rata 78.25. Hasil penelitian ini didukung oleh teori yang dikemukakan oleh Woolnough dalam Rustaman, dkk yang mengatakan bahwa praktikum yang dilakukan dilaboratorium dapat membagkitkan motivasi belajar IPA dan menunjang materi pelajaran sehingga siswa lebih memahami konsep materi yang telah diberikan (Rustaman., 2010). Amien juga mengemukakan bahwa praktikum merupakan salah satu kegiatan laboratorium yang sangat berperan dalam meningkatkan hasil belajar siswa dan menunjang keberhasilan proses belajar mengajar IPA (Amien M., 2012) Penelitian ini juga didukung oleh penelitian sebelumya yang dilakukan oleh Simalango A.N dan Zainuddin M, yang menyimpulkan bahwa hasil belajar dengan metode praktikum lebih baik dari pada hasil belajar yang tidak memakai metode praktikum pada pokok bahasan laju reaksi. (Simalango A. \& Zainuddin M., 2013).

Pengaruh pemanfaatan laboratorium IPA terhadap hasil belajar siswa, telah dikemukakan sebelumnya bahwa untuk pengujian hipotesis digunakan uji-t dengan taraf signifikansi $\alpha=0,05$. Syarat yang harus dipenuhi untuk pengujian hipotesis adalah data yang diperoleh berdistribusi normal dan mempunyai variansi yang homogen setelah dilakukan pengujian maka didapatkan data yang berdidtribusi normal dan mempunyai varians homogen. Berdasarkan analisis data statistik deskriptif, inferensial dan uji hipotesis nilai hasil belajar dengan memanfatkan laboratorium IPA dapat meningkatkan hasil belajar siswa.

Pemanfaatan laboratorium (praktikum) untuk pembelajaran IPA berpengaruh positif terhadap hasil belajar siswa. Hasil penelitian ini didukung oleh teori Mulyasa yang mengemukakan bahwa laboratorium merupakan salah satu sumber belajar karena melalui kegiatan pemanfaatan laboratorium dapat memberikan kemudahan peserta didik dalam memperoleh sejumlah informasi, pengetahuan dan pengalaman, sehingga hasil 
belajar pada siswa lebih meningkat dibandingkan dengan pembelajaran tanpa melakukan pemanfatan laboratorium (Mulyasa E., 2012) Dan pendapat tersebut diperkuat oleh Garry dan Kingsley menyatakan bahwa hasil belajar muncul melalui praktikum atau latihan (Conny R. Semiawan., 2009) Penelitian ini sejalan dengan penelitian yang dilakukan oleh Elvita Yeni pada siswa kelas X SMA Negeri 3 Rambah Hilir, pada bidang studi Biologi menyatakan bahwa hasil belajar IPA lebih baik dengan menggunakan metode praktikum dari pada menggunakan pembelajaran konvensional. (Elvita Yeni., 2015) dan Yuliana, dkk menyebutkan bahwa terdapat pengaruh positif penggunaan laboratorium terhadap hasil belajar peserta didik dapat dilihat dari perolehan nilai rata-rata dari 32,75 menjadi 82,70 dan diperoleh $t_{\text {hitung }}>t_{\text {tabel }}$ yaitu $5.22>1,729$ (Yuliana dkk., 2016).

\section{KESIMPULAN}

Berdasarkan analisis data dan pembahasan hasil penelitian, maka dapat peneliti berikan kesimpulan bahwa, hasil belajar siswa sebelum pemanfaatan laboratorium IPA memperoleh nilai rata-rata pada kelas pretest yaitu 52 berdasarkan kategori hasil belajar berada pada kategori rendah, hasil belajar siswa setelah pemanfaatan laboratorium IPA memperoleh nilai rata-rata pada kelas postest 78,25 berdasarkan kategori hasil belajar berada pada kategori tinggi, terdapat pengaruh positif antara pemanfaatan laboratorium IPA terhadap hasil belajar siswa pada mata pelajaran IPA, setelah dilakukan uji $\mathrm{t}$ diperoleh $\mathrm{t}_{\text {hitung }}=8,33$ dan $\mathrm{t}_{\text {tabel }}=2,042$ maka $\mathrm{t}_{\text {hitung }}>\mathrm{t}_{\text {tabel }}$ atau $8,33>2,042$.

\section{DAFTAR PUSTAKA}

Abdur, Simalonga \& Zainuddin M. (2013). Pengaruh pemakaian metode praktikum terhadap hasil belajar siswa pada pokok bahasan laju reaksi. Jurnal Pendidikan Matematika dan Sains ISSN 3(1):29-39.

Amien, M. (2012). Biologi 2 Untuk Sekolah Menengah, Jakarta: Balai Pustaka.

Djamarah SB \& Zain A. (2012). Strategi Belajar Mengajar. Jakarta: PT Rineka Cipta.

Depdiknas. (2013). Kurikulum Berbasis Kompetensi Mata Pelajaran Biologi Sekolah Menengah Umum. Jakarta: Pusat Kurikulum Balitbang Depdiknas.

Feyzioglu B. (2012). An investigation of the relationship beetwen science process skills with efficient laboratory use and science achievement in chemistry education. Journal of Turkish Science Education 6(3):114-132.

Hofstein A. \& Naaman R.M. (2011). The Laboratory In Science Education: The State Of The Art. Journal Of Chemitry Education and Prctice 8 (2):105-107.

Mulyasa, E. (2012). Strategi Pembelajaran Inovatif Kontemporer, Bandung: PT. Remaja Rosdakarya.

Novianti Nur, Raina. (2010). Kontribusi Pengelolalan Laboratorium Dan Motivasi Belajar Siswa Terhadap Efektifitas Proses Pembelajaran.

Rustaman, N. dkk. (2010). Pokok-Pokok Pengajaran Biologi dan Kurikulum, Jakarta: Depdikbud.

Sardiman A. M. (2010). Interaksi Dan Mativasi Belajar Mengajar, Jakarta: Raja Grafindo Persada.

Semiawan, Conny R. (2009). Perkembangan dan Belajar Peserta Didik, Bandung: Depdikbud.

Sugiyono. (2012). Metode Penelitian Kuantitatif, Kualitatif dan Kombinasi Mixed Method, Bandung: Alfabeta.

Wardani, K S. K. dkk. (2016). Pengembangan Pembelajaran IPA Terpadu Dengan Seting Inquiry Laboratorium untuk meningkatkan konsep dan keterampilan proses sains siswa SMP, Jurnal pendidikan.

Yuliana, dkk. (2016). Pengaruh Penggunaan Laboreatorium Terhadap Hasil Belajar Peserta Didik SMPN 3 Palakka Kabupaten Bone, Jurnal pendidikan.

Yeni Elvita. (2015). Pengaruh Penggunaan Pembelajaran Praktikum Dalam Pembelajaran Biologi di SMA Negeri 3 Rambah Hilir. Jurnal Pendidikan MIPA, Vol. ISSN: 1412-0917 No. 1. 